Bangladesh J. Plant Taxon. 23(1): 33-43, 2016 (June)

(C) 2016 Bangladesh Association of Plant Taxonomists

\title{
TYPIFICATION OF FOURTEEN NAMES OF TWELVE RECOGNIZED TAXA IN LEUCAS R. BR. (LAMIACEAE) AND ONE NEW COMBINATION
}

\author{
RAJEev KUMAR SingH ${ }^{1}$ \\ Botanical Survey of India (BSI), Southern Regional Centre (SRC), TNAU Campus, \\ Lawley Road, Coimbatore 641 003, Tamil Nadu, India
}

Keywords: Isolectotype; Isoneotype; Lectotype; Neotype; Syntype; Leucas.

\begin{abstract}
Eight binomials of six recognized species of Indian Leucas R. Br. are lectotypified, namely, Leucas beddomei (Hook. f.) Sunojk. \& P. Mathew, L. diffusa Benth., L. helianthemifolia Desf., L. nepetifolia Benth., L. pilosa Benth., L. pilosa Benth. var. pubescens Benth., L. ternifolia Desf. and L. vestita Benth. Two recognized taxa are neotypified, namely, L. angularis Benth. and L. lanata Benth. var. candida Haines. $L$. lanata Benth. var. candida Haines is raised to species rank as L. candida (Haines) R.Kr. Singh. L. pilosa Benth. is added to the flora of India. Additionally the following four recognized endemic species of Leucas of Myanmar are also lectotypified, Leucas collettii Prain, L. helferi Hook. f., L. ovata Benth. and L. teres Benth.
\end{abstract}

\section{Introduction}

During the present study on the systematics of Leucas in India, a total of 22 taxa have already been lectotypified (Singh, 2015). In the present communication, eight names of six recognized species of Indian Leucas are lectotypified and two names of two recognized taxa are neotypified here to avoid any ambiguity in the application of these names, because no specific herbarium sheet was cited as holotype in protologue of these taxa and also not lectotypified in earlier works (Singh, 2001; Sunojkumar and Mathew, 2002, 2008; Sunojkumar, 2008; Singh, 2015). The variety candida Haines of $L$. lanata Benth. is raised to species rank and $L$. pilosa Benth., which was earlier considered as endemic to Myanmar, is now added to the Flora of India. Further, during the present study on Leucas in India, author studied type specimens of Leucas (held at CAL and K), which are specimens of species that are endemic to Myanmar. These are lectotypified here. While designating lectotypes and neotypes, the guidelines of Art. 9.2, 9.23, 9.3(c) and 9.6 and recommendations 9A, 9B, 9C and 9D of the Melbourne Code (McNeill et al., 2012) were followed.

\section{Typification of Indian Leucas}

1. Leucas angularis Benth., Pl. Asiat. Rar. (Wallich) 1: 62 (1830).

Type citation: "ex Ceylona. (Herb. Lindley.)"

Neotype (here designated): India, Tamil Nadu, Glen Fall, Kodaikanal Hills, 15 Oct 1919, Jacob 16135 (MH41559!); isoneotype: MH41558!. (Fig. 1)

Distribution: India (Kerala and Tamil Nadu) and Sri Lanka.

Notes: The above neotype is required as the original collection or gathering on the basis of which Leucas angularis was described is not known to exist. Within the protologue, Bentham (1830) cited only 'ex Ceylona. (Herb. Lindley.)' but did not provide any further information. Bentham's types are held at K and Lindley's at BM, CGE and K. However, attempts to locate type

${ }^{1}$ Email: rksbsiadsingh@yahoo.co.in 
specimens in these herbaria were unsuccessful. Since no original material of the species appears to be extant, the specimen from MH41559 is chosen here as the neotype. The specimen selected is well preserved, has mature leaves and well developed flowers.

2. Leucas beddomei (Hook. f.) Sunojk. \& P. Mathew, Rheedea 12(2): 170 (2002).

Leucas hirta (B. Heyne ex Roth) Spreng. var. beddomei Hook. f., Fl. Brit. India 4: 687 (1885).

Type citation: "Chambra Peek, Wynaad, alt. $5000 \mathrm{ft}$., Beddome"

Lectotype (here designated): India, Kerala, Wynaad [Wayanad], Chambra Peak, $5000 \mathrm{ft}$., March 1880, Beddome s.n. (K000929538!); isolectotype: BM000950511!. (Fig. 2)

Distribution: India, endemic and rare (Kerala, restricted to Wayanad district).

Notes: J.D. Hooker (1885) described Leucas hirta var. beddomei on the basis of specimens collected by Beddome from Chambra Peak, Wynaad, but no specific herbarium sheet was designated as the holotype nor did he mention the name of herbarium where the specimens were housed. Two herbarium sheets, collected by Beddome from Chambra Peek, Wynaad, with J.D. Hooker's annotation 'L. hirta var. beddomei Hf' were traced (BM000950511 and K000929538). Of these two, the better preserved K000929538, is designated here as the lectotype as it agrees well with the protologue and also in having dissected flower parts pasted on the sheet.

Singh (2001) cited the type information as "Holotype : India, Chambrapeek, Wynaad, 5000 ft., Beddome s.n. (BM)" and Sunojkumar and Mathew (2002) as "Type: India, Kerala, Wayanad, Chembra peak, 5000 ft., Beddome s.n. - type of Leucas hirta var. beddomei Hook. f. (holotype $\mathrm{K}$, Cibachrome photo!)". Although, they cited BM and K as housing the holotype, but their citation of holotype cannot be corrected to lectotype as per Article 9.23 of ICN 2012, which state that 'On or after 1 January 2001, lectotypification or neotypification of a name of a species or infraspecific taxon is not effected unless indicated by use of the term "lectotypus" or "neotypus", its abbreviation, or its equivalent in a modern language'. They also did not mention the phrase, "designated here" or its equivalent according to Article 7.10.

\section{Leucas candida (Haines) R.Kr. Singh, comb. et stat. nov.}

Leucas lanata Benth. var. candida Haines, Bot. Bihar Orissa 4: 747 (1922).

Type citation: "Var. candida occurs on the hills of the Central Provinces", "It possibly occurs on the higher Sirguja mountains."

Neotype (here designated): India, Tamil Nadu, Nilgiris district, Marappalam-Burliar road, 1225 m, 29 Apr 1971, Rathakrishnan 38130 (MH73387!); isoneotype: MH73388!. (Fig. 3)

Distribution: India, endemic (Madhya Pradesh, Odisha and Tamil Nadu).

Notes: The above neotype is required as the original collection or gathering on the basis of which Leucas lanata var. candida was described is not known to exist. Within the protologue, Haines (1922) cited only the locality but did not provide the date of collection, number of collection/gathering and the name of herbarium where the specimens were housed. Haines's types are known to exist at $\mathrm{K}$ and some at CAL, I tried to trace the type specimens in these two herbaria but no specimen was found extant. Since no original material of the species appears to be extant, the specimen from MH (MH73387) is chosen here as the neotype. The specimen selected is well preserved, has mature leaves and well developed flowers. 

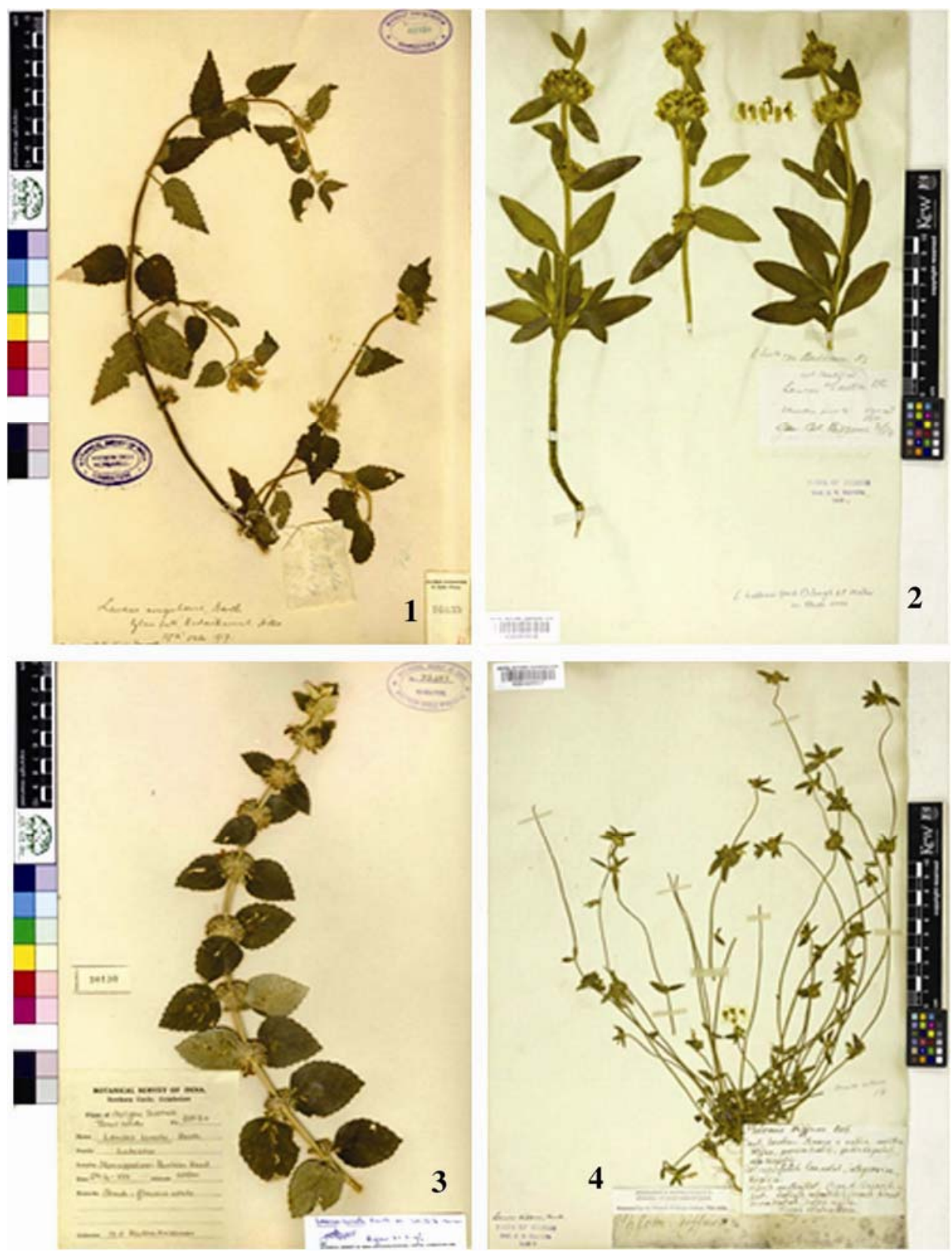

Figs 1-4: 1. Neotype of Leucas angularis Benth. (MH, Accesssion no. 41559, (C) Botanical Survey of India, SRC, Coimbatore). 2. Lectotype of Leucas beddomei Sunojk. \& P. Mathew (K000929538, (C) the Board of Trustees of the Royal Botanic Gardens, Kew). 3. Neotype of Leucas candida R.Kr. Singh (MH, Accession no. 73387, (C) Botanical Survey of India, SRC, Coimbatore). 4. Lectotype of Leucas diffusa Benth. (K000929557, (C) the Board of Trustees of the Royal Botanic Gardens, Kew). 


\section{Key to distinguish Leucas candida from L. lanata}

1. Leaves broadly ovate-rounded, $1.5-7 \times 1.3-5.5 \mathrm{~cm}$, veins not impressed above, pubescent above, tomentose beneath, dark above on maturity; petioles $0.8-2 \mathrm{~cm}$ long; calyx pubescent, teeth $0.6-0.9 \mathrm{~mm}$ long; corolla tube included within calyx, lower lip 1.2-1.3 cm long; nutlets smooth, rounded at apex

\section{L. candida}

- Leaves ovate-lanceolate or ovate-oblong, $1-4 \times 0.5-1.6 \mathrm{~cm}$, veins distinctly impressed above, tomentose above, silky beneath, grey on maturity; petioles absent in upper leaves, or short (0.3-0.9 cm long) in lower ones; calyx tomentose, teeth $1.3-1.6 \mathrm{~mm}$ long; corolla tube usually exserted from calyx, lower lip $<0.8-0.9 \mathrm{~cm}$ long; nutlets tuberculate, truncate at apex

\section{L. lanata}

4. Leucas diffusa Benth., Labiat. Gen. Spec. : 615 (1834).

Leucas dimidiata sensu Benth, Pl. Asiat. Rar. (Wallich) 1: 61 (1830), non (Roth) Spreng. (1825).

Type citation: "L. dimidiata. Benth. in Wall. PI. As. Rar. non Roth.", "Hab. in Indiae Orientalis Peninsula Herb. Madr. (h. s. sp. e Mus. Angl. Ind.)"

Lectotype (here designated): India, Penins. Indiae Orientalis [Peninsular India], Madras, without date, Rottler s.n. (K000929557!). (Fig. 4)

Residual syntypes: Without locality, 1829, Herb. Madr., Wallich s.n. (K000929558!); Without locality, without date, Herb. Madr., Wallich cat. n. 2528 E (CAL362830!).

Distribution: India, endemic (Andhra Pradesh, Delhi, Karnataka, Kerala and Tamil Nadu).

Notes: Bentham (1834) described Leucas diffusa based on the specimens from Peninsular India and Herb. Madr., but no type was indicated nor did he cite the name of the collector(s), date of collection, collection number and the name of herbarium where the specimens were housed. In the protologue, he mentioned that his earlier L. dimidiata in Plantae Asiaticae Rariores (Wallich) is $L$. diffusa now. As per the specifications given in protologues of $L$. diffusa and L. dimidiata sensu Benth. (1830) in Plantae Asiaticae Rariores, it is clear that Peninsular India specimen belongs to Herbarium Rottlerianum and specimens of Herb. Madr. belongs to Wallich cat. $n$. 2528 E. Two specimens of Herb. Madr. (K000929558 and CAL362830) and one of Penins. Indiae Orientalis was traced (K000929557). Since Bentham worked at K, only the two specimens at K have been considered for lectotypification. The collection K000929557 is better preserved and more complete than the other, it agrees well with the protologue and also has dissected flower parts and short descriptive notes pasted on the sheet. Therefore, this collection is here designated as the lectotype.

5. Leucas helianthemifolia Desf., Mém. Mus. Hist. Nat. 11: 2 (1824).

Type citation: "M. Lechenault", "Cette jolie espèce est indigène des la presqu'île de I'Inde; elle croît sur la base des montagnes de Nelligerry."

Lectotype (here designated): India, montagnes de Nelliggerry [Nilgiri Mountains], without date, Leschenault 34 (P00738007!). (Fig. 5)

Residual syntype: India, montagnes de Nelliggerry [Nilgiri Mountains], without date, Leschenault s.n. (P00215013!).

Leucas ternifolia Desf., Mém. Mus. Hist. Nat. 11: 4 (1824).

Type citation: "M. Lechenault", "elle croît également sur la base des montagnes de Nelligerry." 
Lectotype (here designated): India, montagnes de Nelliggerry [Nilgiri Mountains], without date, Leschenault 206 (P00738006!); isolectotype: P00215014!. (Fig. 6)

Distribution: India, endemic (Kerala and Tamil Nadu).

Notes: Desfontaines (1824) described Leucas helianthemifolia based on a gathering by Leschenault from Nilgiri hills, India but no specific herbarium sheet was designated as the holotype nor did he mention the name of herbarium where the specimens were housed. Within the protologue, Desfontaines gave the precise locality and collector name but did not provide the number and date of collection. Two herbarium sheets, collected by Leschenault from Nilgiri Mountains, India are held at P (P00215013 and P00738007). The better preserved sheet, P00738007, is chosen here as the lectotype because the illustration in the protologue is based on this and it agrees well with the protologue.

Leucas ternifolia was described by Desfontaines (1824) on the basis of specimens collected by Leschenault from Nilgiri Mountains, India but no specific herbarium sheet was designated as the holotype nor did he mention the name of herbarium where the specimens were housed. In the protologue, Desfontaines gave the precise locality and collector name but did not provide the number and date of collection. Two herbarium sheets at P (P00215014 and P00738006), collected by Leschenault from Nilgiri Mountains, India were traced. Of these, the best one, P00738006, is chosen here as the lectotype because the illustration in the protologue is based on this and it agrees well with the protologue.

6. Leucas nepetifolia Benth., Pl. Asiat. Rar. (Wallich) 1: 62 (1830).

Type citation: "Hab..... (Herb. Madr.)"

Lectotype (here designated): Without locality, without date, Herb. Madr., Wallich cat. n. 2526 (K001116355!); isolectotype: CAL362295!. (Fig. 7)

Distribution: India, endemic and rare (Andhra Pradesh, Karnataka and Tamil Nadu).

Notes: In the protologue of Leucas nepetifolia, Bentham (1830) indicated only 'Hab. . . . . (Herb. Madr.)' as type citation but did not provide the name of collector, date of collection, locality, number of collection/gathering and the name of herbarium where the specimens were housed. Pertaining to the specification given in protologue, two specimens of L. nepetifolia of Herb. Madr. (CAL362295 and K001116355), belonging to Wallich cat. $n$. 2526 were traced and better preserved sheet, K001116355, is designated here as the lectotype as it agrees well with the protologue.

7. Leucas pilosa Benth., Pl. Asiat. Rar. (Wallich) 1: 62 (1830).

Type citation: "Hab. $\alpha$. ad ripas Irawaddi."

Lectotype (here designated): Myanmar, Irawaddi, 1829, Wallich cat. n. 2058 [1] (K000929509!). (Fig. 8)

Residual syntypes: Myanmar, Irawaddi, 1826, Wallich cat. n. 2058 [1] (K001115020! and CAL362482!).

Leucas pilosa Benth. var. pubescens Benth., Pl. Asiat. Rar. (Wallich) 1: 62 (1830) et Labiat. Gen. Spec. 609 (1834) et Prodr. (A. P. de Candolle) 12: 526 (1848).

Type citation: " $\beta$ Rajemahl."

Lectotype (here designated): India, Jharkhand, Rajemahl [Rajmahal], 7 Aug 1820, Wallich cat. n. 2058 [ß] (K001115022!). (Fig. 9) 

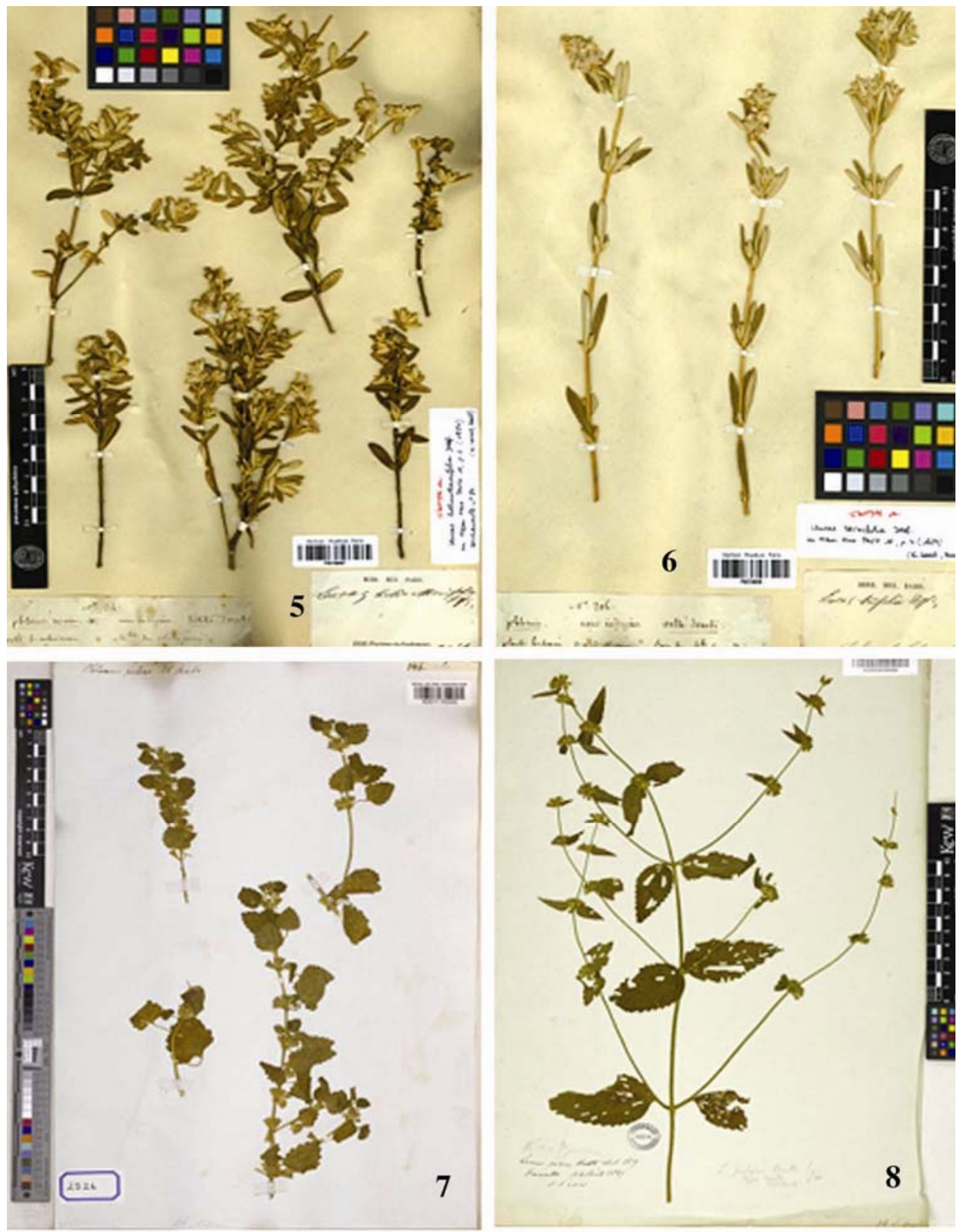

Figs 5-8: 5. Lectotype of Leucas helianthemifolia Desf. (P00738007, (C) Muséum National D'Histoire Naturelle, Paris). 6. Lectotype of Leucas ternifolia Desf. (P00738006, C) Muséum National D'Histoire Naturelle, Paris). 7. Lectotype of Leucas nepetifolia Benth. (K001116355, (C) the Board of Trustees of the Royal Botanic Gardens, Kew). 8. Lectotype of Leucas pilosa Benth. (K000929509, (C) the Board of Trustees of the Royal Botanic Gardens, Kew). 
Residual syntypes: India, Jharkhand, Rajemahl [Rajmahal], 6 Aug 1820, Wallich cat. $n .2058$

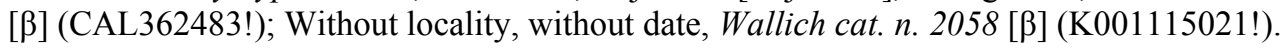

Distribution: India (Jharkhand, Madhya Pradesh and Uttarakhand) and Myanmar.

Notes: Bentham (1830) described Leucas pilosa based on the specimens from Irawaddi, but no specific herbarium sheet was designated as the holotype nor did he cite the name of the collector, date of collection, collection number and the name of herbarium where the specimens were housed. Pertaining to the specification given in protologue, three specimens from Irawaddi of Wallich cat. n. 2058 [1] were known (CAL362482, K000929509 and K001115020). Only the two sheets at $\mathrm{K}$ have been considered here to choose the lectotype for this name because Bentham worked at K. The herbarium specimen, K000929509 belongs to herbarium Benthamianum and is designated here as the lectotype as it agrees well with the protologue.

In the protologue of Leucas pilosa var. pubescens, Bentham (1830) indicated only ' $\beta$ Rajemahl.' as type citation but did not provide the name of collector, date of collection, number of collection/gathering and the name of herbarium where the specimens were housed. Pertaining to the specification given in protologue, three specimens from Rajemahl [Rajmahal] of Wallich cat. n. $2058[\beta]$ were traced (CAL362483, K001115021 and K001115022), which should be considered as original material. Only the two K specimens are considered as suitable lectotypes specimens for this name. The best one and better preserved sheet, K001115022, is designated here as the lectotype as it agrees well with the protologue.

J.D. Hooker (1885) did not include Leucas pilosa Benth. var. pubescens Benth. in the Flora of British India, furthermore, he did not mention the place of occurrence of this variety. $\mathrm{He}$ mentioned the occurrence of L. pilosa, only in Burma [Myanmar]. Singh (2001) in Monograph of Indian Leucas did not clearly conclude the identity of var. pubescens and simply wrote that this variety was considered conspecific to $L$. pilosa by earlier workers and it may probably be a form of $L$. decemdentata (Willd.) Sm., but he mention the species $L$. pilosa Benth. is endemic to Myanmar. Bentham (1830) described var. pubescens on the basis of specimens from Rajmahal, Jharkhand state, India. In Labiatarum Genera et Species and in Prodromus Systematis Naturalis Regni Vegetabilis (DC.), he cited Royle's collection from Deyra Dhoun [Dehra Dun] and Wallich's collection from Rajemahl [Rajmahal] for var. pubescens. After study of type specimens of var. pubescens from Rajmahal (K and CAL) and Royle's collection from Dehra Dun (DD), it is now concluded that this variety pubescens is conspecific with L. pilosa Benth. Hence, Leucas pilosa Benth. is now added to Indian flora.

8. Leucas vestita Benth., Pl. Asiat. Rar. (Wallich) 1: 61 (1830), p.p. et Labiat. Gen. Spec. 613 (1834), p.p. et Prodr. (A. P. de Candolle) 12: 530 (1848).

Type citation: "Hab. in Sillet", "Hab. in Indiae orientalis provincia Sillet Wallich ! et Peninsulae montibus Madurensibus Wight! (h. s. sp. e Mus. Angl. Ind. et comm. a cl. Wight.)", "In Indiae orientalis Peninsulae montibus Madurensibus (Wight ! n. 2530).-Wight ic. 2, t. 338."

Lectotype (here designated): India, Peninsula Ind. orientalis [Peninsular India], without date, Wight 2530 (K000929531!). (Fig. 10)

Residual syntype: Without locality, without date, 1829, Herb. Wight, Wallich s.n. (K000929529, p.p.!).

Distribution: India, endemic (Andhra Pradesh, Karnataka, Kerala and Tamil Nadu).

Notes: In Plantae Asiaticae Rariores (Wallich), Bentham (1830) indicated only 'Hab. in Sillet' as type citation for Leucas vestita, but did not provide the name of collector, date of collection, number of collection and the name of herbarium where the specimens were housed. 
Later in 1834 (Labiatarum Genera et Species), he amended the description and cited 'Hab. in Indiae orientalis provincia Sillet Wallich! et Peninsulae montibus Madurensibus Wight! (h. s. sp. e Mus. Angl. Ind. et comm. a cl. Wight.)' as type. Again in 1848 (Prodromus Systematis Naturalis Regni Vegetabilis), he amended the description and cited type as 'In Indiae orientalis Peninsulae montibus Madurensibus (Wight ! n. 2530).-Wight ic. 2, t. 338.' So, finally L. vestita was correctly described by Bentham in Prodromus Systematis Naturalis Regni Vegetabilis (DC.) and it is endemic to south India. Pertaining to these specifications, two specimens (K000929529, p.p. and K000929531) from herbarium Benthamianum were traced. Of these two, the best one, K000929531, is designated here as the lectotype, as it agrees well with the protologue. The herbarium sheet K000929529 is a mixed collection, the upper half plant specimen belongs to Herb. Wight (syntype of L. vestita Benth. var. vestita), whereas the lower half is of Beddome from Anamallay hills (syntype of $L$. vestita Benth. var. sericostoma Hook. f.). Two herbarium sheet of Wallich cat. n. 2039 (K001114953! and CAL362672!) collected from Sillet [Sylhet] though written as $L$. vestita Benth. by Wallich are actually $L$. ciliata Benth. The herbarium sheet K000929542 of Wallich cat. $n$. 2046 [ $\beta$ ] collected from Sillet [Sylhet] was identified as $L$. vestita by Bentham (1834) in Labiatarum Genera et Species and later in 1848 treated as L. ciliata var. hirsuta in Prodromus Systematis Naturalis Regni Vegetabilis (DC.).

\section{Typification of Leucas species endemic to Myanmar}

1. Leucas collettii Prain, J. Asiat. Soc. Bengal, Pt. 2, Nat. Hist. 59(4): 313 (1891).

Type citation: "UPPER BURMA; Popah hill, 5000, Collett n. 29."

Lectotype (here designated): Myanmar, Popah hill, 5000 ft., Dec 1887, Collett 29 (CAL0000020543!); isolectotype: K000929569!. (Fig. 11)

Notes: Prain (1891) described Leucas collettii based on the specimens collected from Popah hill, Myanmar, but no specific herbarium sheet was designated as the holotype nor did he mention the name of herbarium where the specimens were housed. Only two herbarium specimens of Collett 29 are now extant, CAL0000020543 and K000929569. Of these two, CAL0000020543, is designated here as the lectotype as it agrees well with the protologue and also includes short descriptive notes and drawing of flower on the sheet by Prain.

2. Leucas helferi Hook. f., Fl. Brit. India 4: 681 (1885).

Type citation: "TENASSERIM; Helfer."

Lectotype (here designated): Myanmar, Tenasserim, without date, Helfer 4046 (CAL0000020544!). (Fig. 12)

Notes: J.D. Hooker (1885) described Leucas helferi based on the specimens collected by Helfer from Tenasserim but no specific herbarium sheet was designated as the holotype nor did he cited the date of collection, collection number and the name of herbarium where the specimens were housed. Pertaining to the specification given in protologue only one specimen of $L$. helferi collected by Helfer from Tenasserim is extant now at CAL (CAL0000020544). The types of J.D. Hooker's are known to be at K, sometimes at BM, E and P, but no original materials are found there. Although, the specimen CAL0000020544 was not examined by J.D. Hooker, but was collected by Helfer from Tenasserim and it is a part of original gathering. So, this should be considered as original material according to Art. 9.3(c) of Melbourne Code (McNeill et al. 2012) and is chosen here as the lectotype as it agrees well with the protologue. 
3. Leucas ovata Benth., Pl. Asiat. Rar. (Wallich) 1: 61 (1830).

Type citation: "Wall. Cat. Herb. Ind. n. 2057.", "Hab. ad ripas Irawaddi."

Lectotype (here designated): Myanmar, Irawaddi, 1829, Wallich cat. n. 2057 (K000929508!). (Fig. 13)

Residual syntypes: Myanmar, Irawaddi, 1826, Wallich cat. n. 2057 (K001115019); Myanmar, Irawaddi, without date, Wallich cat. $n .2057$ (CAL362481!).
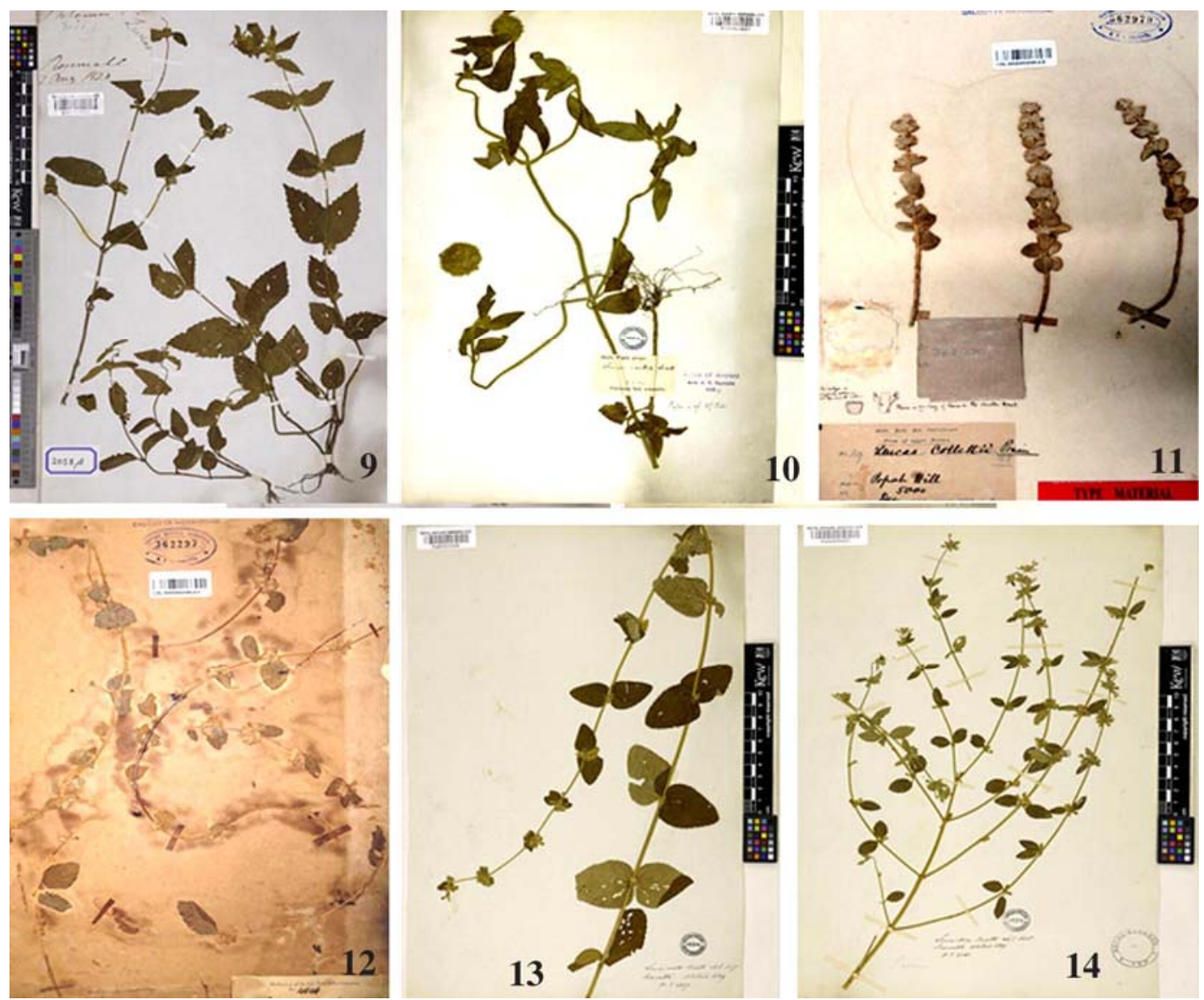

Figs 9-14: 9. Lectotype of Leucas pilosa Benth. var. pubescens Benth. (K001115022, (C) the Board of Trustees of the Royal Botanic Gardens, Kew). 10. Lectotype of Leucas vestita Benth. (K000929531, (C) the Board of Trustees of the Royal Botanic Gardens, Kew). 11. Lectotype of Leucas collettii Prain (CAL0000020543, (C) Central National Herbarium, Howrah). 12. Lectotype of Leucas helferi Hook. f. (CAL0000020544, (C) Central National Herbarium, Howrah). 13. Lectotype of Leucas ovata Benth. (K000929508, (C) the Board of Trustees of the Royal Botanic Gardens, Kew). 14. Lectotype of Leucas teres Benth. (K000929483, (C) the Board of Trustees of the Royal Botanic Gardens, Kew).

Notes: Bentham (1830) described Leucas ovata based on the gathering from Irawaddi of Wallich cat. $n$. 2057, but no specific herbarium sheet was designated as the holotype nor did he mention the date of collection and name of herbarium where the specimens were housed. Pertaining to the specification given in protologue, three specimens from Irawaddi of Wallich cat. 
n. 2057 were known (CAL362481, K000929508 and K001115019). Only the two specimens at K have been considered here to choose the lectotype specimen for this name because Bentham worked at K. The herbarium sheet K000929508 belongs to herbarium Benthamianum and is designated here as the lectotype as it agrees well with the protologue.

4. Leucas teres Benth., Pl. Asiat. Rar. (Wallich) 1: 62 (1830).

Type citation: "Wall. Cat. Herb. Ind. n. 2060", "Hab. ad ripas Irawaddi."

Lectotype (here designated): Myanmar, Irawaddi, 1829, Wallich cat. n. 2060 (K000929483!).

Residual syntypes: Myanmar, Irawaddi, 1826, Wallich cat. n. 2060 (K001115024!); Myanmar, Irawaddi, without date, Wallich cat. $n .2060$ (K000929482!). (Fig. 14)

Notes: Bentham (1830) described Leucas teres based on the gathering from Irawaddi of Wallich cat. $n$. 2060, but no specific herbarium sheet was designated as the holotype nor did he mention the date of collection and name of herbarium where the specimens were housed. Pertaining to the specification given in protologue, three specimens from Irawaddi of Wallich cat. n. 2060 were known (K000929482, K000929483 and K001115024). Of these, the herbarium sheet K000929483, from the Benthamianum herbarium, is designated here as the lectotype as it agrees well with the protologue.

\section{Acknowledgements}

The author is thankful to Dr. P. Singh, Director, Botanical Survey of India (BSI), Kolkata and Dr. G.V.S. Murthy, Head of Office, Botanical Survey of India, Southern Regional Centre, Coimbatore for facilities. I am also grateful to the Curators of BM, CAL, CGE, E, DD, K, MH and $\mathrm{P}$ for information and images of type specimens.

\section{References}

Bentham, G. 1830. Leucas. In: Wallich N (ed.), Plantae Asiaticae Rariores: or, Descriptions and figures of select number of unpublished East Indian plants 1: 60-62. Treuttel and Würtz, London.

Bentham, G. 1834. Labiatarum Genera et Species 6: 609, 613 \& 615. James Ridgway \& Sons, London.

Bentham, G. 1848. Leucas. In: de Candolle AP (ed.), Prodromus Systematis Naturalis Regni Vegetabilis 12: 523-533. Sumptibus Victoris Masson, Paris.

Desfontaines, R.L. 1824. Observations Sur les genres Leucas et Phlomis. Description de plusieurs Espèces. Mémoires du Muséum d'Histoire Naturelle, Paris 11: 1-10.

Haines, H.H. 1922. The Botany of Bihar and Orissa 4: 747-748. Adlard \& Son \& West Newman Ltd., London.

Hooker, J.D. 1885. The Flora of British India 4: 680-691. L. Reeve \& Co., London.

Mabberley, D.J. 2008. Mabberley's Plant-Book: A portable dictionary of plants, their classification and uses. Third Edition. Cambridge University Press, Cambridge, pp. 485.

McNeill, J., Barrie, F.R., Buck, W.R., Demoulin, V., Greuter, W., Hawksworth, D.L., Herendeen, P.S., Knapp, S., Marhold, K., Prado, J., Proud'homme van Reine, W.F., Smith, G.F., Wiersema, J.H. and Turland, N.J. (eds.). 2012. International Code of Nomenclature for algae, fungi and plants (Melbourne Code): Adopted by the Eighteenth International Botanical Congress, Melbourne, Australia, July 2011. Regnum Vegetabile 154: 1-274.

Prain, D. 1891. Noviciae Indicae. III. Some additional species of Labiatae. J. Asiat. Soc. Bengal, Pt. 2, Nat. Hist. 59(4): 294-318.

Singh, R.Kr. 2015. Lectotypification of Indian taxa of Leucas (Lamiaceae). Telopea 18: 395-424.

Singh, V. 2001. Monograph on Indian Leucas R. Br. (Dronapushpi) Lamiaceae. Scientific Publishers, Jodhpur, India. 
Sunojkumar, P. 2008. Taxonomical change in Leucas ciliata Benth. and Leucas vestita Benth. (Lamiaceae: Lamioideae). Candollea 63(1): 81-83.

Sunojkumar, P. and Mathew, P. 2002. Leucas beddomei (Hook. f.) Sunojkumar \& P. Mathew (Lamiaceae), a new status and name for Leucas hirta var. beddomei Hook. f. - a little known endemic from India. Rheedea 12 (2): 169-174.

Sunojkumar, P. and Mathew, P. 2008. South Indian Leucas: A Taxonomic Monograph. Centre for Research in Indigenous Knowledge Science and Culture, Calicut.

(Manuscript received on 14 October 2015; revised on 30 November 2015) 